\title{
A critical assessment of Daniel Groody's conceptualisation of the incarnation and its implication in challenging the church to embrace and respond to migrants' needs
}

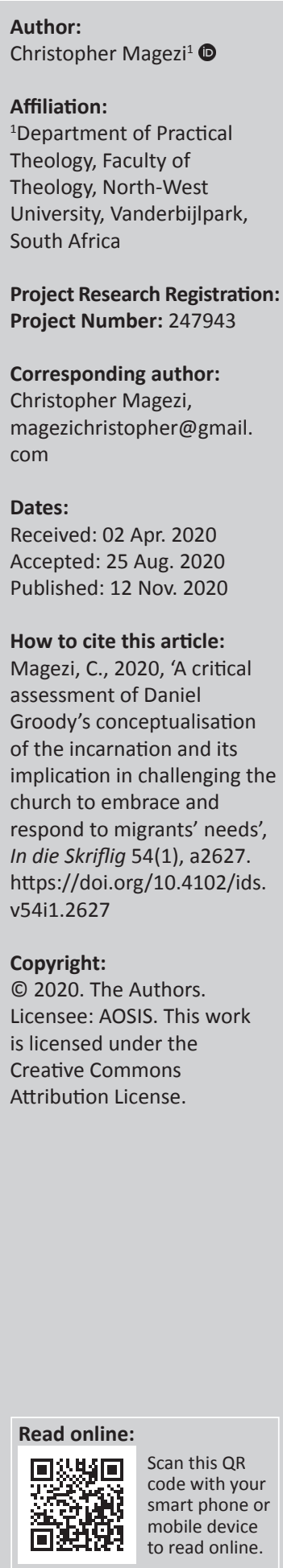

This article identifies the church as obligated by God to respond to migrants' challenges and, as it does so, what is at stake is the theological foundational status of migrant theology challenging the body of Christ to embrace and integrate migrants. With this in mind, this article considers Goody as the leading theologian in migration discourse. He has offered theological foundational status of migration theology that challenges the church to be practically responsive to the plight of migrants. Groody advances the theology of the incarnation as the major theology of migration with far-reaching implications for this subject. Unfortunately, Groody's theology of the incarnation has weaknesses in both conceptualisation and application. In addressing the weaknesses in Groody's conceptualisation and the application of the doctrine of the incarnation in urging the church to be proactively involved in migration issues, this article attempts to move beyond Groody by articulating the doctrine of the incarnation to counteract the weaknesses arising from Groody's conceptualisation and application of the doctrine of the incarnation to migration issues. Thereafter, this article reaches a conceptual convergence with Groody by reinforcing the leading aspects of the incarnation that challenge the Church to respond to migrants' challenges in an effective manner.

Keywords: migration; church; Daniel Groody; migrants' challenges; incarnation; migration theology; anhypostasis; enhypostasis.

\section{Introduction}

\section{A terrain sketch and problem identification}

It is irrefutable that migration affects migrants, as well as migrant sending and hosting nations (Groody 2016:225; Magezi 2018:193-215). However, the focus of this article lies on the church's response to migrants' challenges. Various theologians such as Groody (2016:225-239), Cruz (2010:121) and Magezi (2017:1-4), as well as church councils (i.e. the Church's Commission for Migrants in Europe [CCME] and World Council of Churches [WCC]) understand that the church of God has a role to play in responding to migrants' challenges (Jackson \& Passarelli 2016:5). Stated otherwise: by virtue of being the body of Christ that is sanctioned by God to pursue sympathy and care for desolate people such as migrants (cf. Mt 25:31-46; Heb 13:1-2, etc.), the church has no choice, but to respond to their challenges.

As a result of the aforesaid conception, various responses to migrants' challenges have been offered. For instance, in 2015, thousands of migrants from Africa were reported to have drowned in the Mediterranean Sea whilst trying to cross to Europe (Saunders, Snyder \& Fiddian-Qasmiyeh 2016:1; WCC 2015). Thus, in reacting to these deaths, the General Secretaries of the WCC, CCME and Conference of European Churches jointly issued a comprehensive letter advising their respective member churches and interrelated organisations to utilise sympathetic ecumenical responses to the challenges that migrants, particularly refugees, were encountering before and upon their arrival in Europe (WCC 2015). Nonetheless, Magezi and Magezi (2018:1) note that this comprehensive communication to the churches and related organisations lacks a thoroughly worked out theology of migration that would drive the European response to the refugee crisis. In substantiating the foretasted challenge, Magezi (2018) conducted a qualitative research in South Africa's Gauteng Province. The research, which involved interviewing church leaders, revealed that, firstly, some current South African church leaders premised and justified theological 
rationales for their structured and unstructured migrant ministries on less relevant biblical texts (Magezi 2018:314-316). Secondly, some of the churches did not have structured migrant ministries due to their debatably skewed theological rationales (Magezi 2018:316-320). This clearly means that the biblical theological foundational statuses of some churches' theologies of migration are not thoroughly worked out.

However, among the scholars that are engaging in the theology of migration, Daniel Groody is perceived by Botha (2013:111) as the leading scholar who 'has enriched the quest for a theological missiological perspective on migration'. On the basis of his comprehensive article titled, 'Crossing the divide: foundations of a theology of migration and refugees', Groody (2009) can be considered as the leading theologian in migration discourse. In this article, Groody (2009:642) focuses on the ensuing theological aspects as the theological foundational status of migration theology that offer ways of thinking about theology and migration: (1) Imago Dei: Crossing the Problem-Person Divide; (2) Verbum Dei: Crossing the Divine-Human Divide; (3) Missio Dei: Crossing the Human-Human Divide; and (4) Visio Dei: Crossing the Country-Kingdom Divide. These aforementioned theological aspects of Groody's theology of migration are critical, because they help human beings to cross the borders of divide and overcome barriers that cause the church and, consequently, human beings in general to be uncompassionate to the migrants and refugees on their door step. Nevertheless, among the identified theological aspects of Groody's theology of migration, it is ostensive that Groody (2009:639) views the incarnation as the primary basis of the theology of migration and refugees. In his own words, Groody (2009:639) unswervingly states that 'no aspect of a theology of migration is more fundamental, nor more challenging in its implications, than the incarnation'. This means that, although there are many theological aspects that can be employed to challenge the church to pursue sympathy and care for migrants, it is apparent that Groody considers the incarnation as the leading theological aspect of migration with far-reaching implications.

Nonetheless, although Groody considers the doctrine of the incarnation as the fundamental basis of migration theology with far-reaching implications, it is unfortunate that his doctrine of the incarnation is not thoroughly explained, because he brings the doctrine of the incarnation to respond to migration challenges without identifying and explaining the various theological aspects that he brings together to configure that doctrine. Further, Groody seems to apply the doctrine of the incarnation to challenge the church and, consequently, Christians to embrace and co-exist with migrants in a manner that can possibly pose challenges to the understanding of the doctrine of God if not handled properly. In response to the above challenges that emerge from Groody's doctrine of the incarnation and its application to migration challenges, this article critically assesses Groody's understanding of the said doctrine and its implications on the conduct of the church and Christians in relation to embracing migrants. Further, the article moves beyond Groody by articulating the doctrine of the incarnation to counteract the weaknesses arising from Groody's conceptualisation and application of the doctrine of the incarnation to migration issues. As such, this article is not an abstract adjustment to Groody's theological arguments about migration and the incarnation.

In order to accomplish this objective, this article commences by articulating Groody's understanding of the incarnation doctrine and its intended application to the problems of migration that emerge from his dogma of the incarnation. At this juncture, the weaknesses within Groody's understanding of the incarnation doctrine and its application to migration issues will be identified. Once the limitations embedded in Groody's theological conception and application of the incarnation to migration issues are identified, the second section will attempt to delineate the doctrine of the incarnation in light of the trinitarian doctrine of God, so as to countermand the weaknesses in Groody's conception and application of the incarnation doctrine to migration issues. Once this has been done, the article will conclude by highlighting some overarching findings and arguments.

\section{Groody's conceptualisation of the incarnation and its implications on migration issues \\ Groody's articulation of the doctrine of incarnation in view of sin}

Groody (2009) views humankind as sinful and alienated from God. Humanity was created in the image of God and sin distorted that image (Groody 2009:648; 2016:229-232). When Adam and Eve ${ }^{1}$ sin against God in the Garden of Eden, as related in Genesis 3, the image of God in man gets distorted and thus subjecting humankind to a broken relationship with God and one another (Groody 2009; 2016). At this juncture, this article is not attempting to give an overview of the doctrine of sin. Instead, this article is simply showing that the backdrop of sin is within Groody's theology of migration, as he understands that the negativism divide, narcisstic divide, nationalism and nihilism, as perceived in the contemporary context of migration, are caused by the sin of Adam and Eve as rendered in the narrative of Genesis (Groody 2016:229-232). So, both the Old and New Testament consistently present a need for the restoration of the image of God in humanity, which was distorted by sin (Groody 2009:648). Unfortunately, Groody (2009) does not expound the dogma of the image of God in humanity. Instead, he simply posits that the idea of the image of God (Imago Dei) in humanity that is presented in the Old Testament, is realised in the New Testament through the image of Christ (Magezi \& Magezi 2018:24). Groody (2009:648) understands Christ as the Word of God

1.1 am aware that there are disagreements in the scholarly guild on whethe........ and Eve were real people or not. For instance, Arnold (2008:405), Averbeck (2013:30), Barrick (2013:197) are of the opinion that Adam and Eve were rea historical people, while Beidler (2011) and many more others do not consider them as such. While I note these different views, this article subscribes to the perspective that Adam and Eve were real historical people. I thus agree with Barrick (2013) that:

the biblical account represents Adam as a single individual rather than an archetype or the product of biological evolution, and a number of New Testament there is no need for Jesus, the second Adam, to undo the first Adam's sin and its results. (p. 197) 
(Verbum Dei) who embodies the perfect image of God and, consequently, as the one who helps people to migrate back to God by restoring in them the image of God, which was formerly marred and distorted because of sin. In Groody's understanding, the goal of migration theology is to restore humanity's relationship with God (vertical relationship) and human to human relationship (horizontal relationship) (Groody 2016:228).

In highlighting the need for the restoration of vertical and horizontal relationships, Groody (2009:642-648) is advocating for nothing other than the restoration of the image of God in humanity as the goal of migration theology. The restoration of the image of God in humanity will result in people viewing each other the way God intended it to be from the creation order (Groody 2009). Stated differently, Groody (2016:228) specifies that the 'principal goal of a migration theology is about justice' for the migrants. In his view, Christian theology constitutes two notions of justice, namely internal and external justice (Groody 2016:228). Internal justice refers to an individual's right relationship with God through faith in Christ's redemptive work, whilst external justice refers to one's positive response to the grace of God in and through Christ (Groody 2016). Internal and external justice are interrelated, as one's right relationship with God (internal justice) results in right relationships with one another at every level of people's lives (Groody 2016). Therefore, vertical relationship results in horizontal relationships. Groody (2016:228) advances that internal justice is inherent in Jesus' first and greatest command, namely 'to love the Lord God with all one's heart, soul, and mind' (Mt 22:35-40, Mk 12:28-34 and Lk 10:27a). External justice is intrinsic in Jesus' second greatest commandment, namely 'to love one's neighbour as oneself' (Groody 2016).

At this juncture, the abovementioned understanding of Groody is in accordance with Mounce (1985), Morris (1992), Mitch and Sri (2010:289), and Turner (2008) who all advance Matthew 22:35-40 as one of the central texts in which the proposed commandments are mentioned in Scripture. In other words, these scholars argue that Matthew 22:35-40 reveals that humankind was created to love and serve God, as well as to love fellow humankind (cf. Mitch \& Sri 2010:289). For example, Turner (2008:537) and Morris (1992:563) helpfully observe that, by summarising all the precepts and instructions of the Old Testament in these proposed two commandments in Matthew 22:37-39, Jesus is configuring the linkage that exists between the vertical and horizontal facets of love. The vertical (internal love) speaks about humankind's love for God and the horizontal (external love) speaks about humankind's love for one another (neighbours) as expounded by Morris (1992) in the following manner:

Wholehearted love for God means (vertical love) coming in some measure to see other people as God sees them (man as created in the image of God) and all people as the objects of God's love. Therefore, anyone who truly loves God with all his being must and will love others, and this is expressed in the commandment, 'you shall love your neighbor as yourself'. (p. 563, [author's emphasis])
It is important to note that at the heart of the external or horizontal love is the underlying conception that, due to the problem of sin that marred all spheres of life, humanity, especially those that are from different national, cultural, ethnic and religious backgrounds, struggle to relate to each other (Groody 2016:229).

\section{Groody views the incarnation as central in solving the internal and external justice that was diminished by $\sin$}

In response to the aforementioned internal and external justice that was diminished because of sin, Groody (2009:648) brings the incarnation as central in restoring both. $\mathrm{He}$ commences his doctrine of the incarnation by advancing the idea of the image of God (Imago Dei) that is presented in the Old Testament and fulfilled in the New Testament through the image of Christ (Groody 2009:648). Here, Christ is the Word of God (Verbum Dei) who embodies the perfect image of God and the one who helps people to migrate back to God by restoring in them the image of God that had been marred or distorted because of sin (Groody 2009). Nevertheless, without explaining the trinitarian doctrine of God and how Christ embodies the perfect image of God in man, Groody (2009:648-667) hastens to explain the incarnational mystery of God by heavily relying on Karl Barth's understanding. This is because he quotes Barth extensively throughout his work as he discusses the theological concept of the incarnation. For instance, Groody (2009:649) states that Barth does not mention the term migration in his discussion of the incarnation, but he speaks about the incarnation in terms of 'the way of the Son of God into the far country'. Even though Barth does not mention the term migration in reference to the incarnation, Groody (2009:649) portrays Barth as speaking of the incarnation in reference to the descending of God (in and through Christ) from the eternal place of dwelling (heaven) into the strange territory of sinful and estranged humankind so as to truly identify with them and save them from sin and its consequences, including the broken relation between divine-human and human-human (Groody 2009).

Thereafter, Groody (2009:649) weighs in with the doctrine of kenosis [self-emptying] of Christ as the one that configures the dogma of incarnation. Groody (2009:649) argues that the kenosis concept states that, although Jesus Christ is fully God, he voids himself of his divine privileges by coming down to earth in order to restore humankind's broken relationship with God and with one another (human-human) through his (Jesus') redemptive acts. Groody (2009) explains the kenosis concept in view of the salvation it achieves for humankind in the following manner:

Through the Verbum Dei, Jesus' kenosis and death on the cross, God overcomes the barriers caused by sin, redraws the borders created by people who have withdrawn from God, and enters into the most remote and abandoned places of the human condition. (p. 649)

The above quotation indicates that Groody (2009) views the death of Christ (the very God himself) at the cross as of great 
significance, because he dies for the sins of all people and resurrects from the dead so as to save all mankind that believe in his redemptive acts from sin and all its consequences. In Groody's view (2009), the death of Jesus Christ at the cross is vital, because it is the ultimate expression of God's self-giving love and complete solidarity with all people, including the vulnerable migrants (Groody 2009). However, although Groody (2009:651) does not delve into detail on the issue of the death of Christ, he is of the opinion that the twin understanding of the concept of Christ's kenosis and his subsequent death at the cross, yields important insights and implications for those migrants that are forcibly uprooted and migrated to foreign nations to cope in their new homelands. In Groody's words (2009):

The cross is the ultimate expression of God's self-giving love, God's solidarity with those who suffer, and God's power at work amid human struggle and weakness. The notion of the crucified God and the crucified peoples is a topic that requires in-depth consideration beyond the scope of this article, but this notion is a central dimension of a theology of migration and has tremendous implications for those who are forcibly displaced, especially for addressing the inner wounds that migrants and refugees experience. (p. 651)

Given the abovementioned understanding, Groody (2009:649) insists that the incarnation speaks directly to the venturing of the infinite and transcendent God 'into the broken and sinful territory of the human condition in order to help men and women, lost in their earthly sojourn, find their way back home to God'. However, in interconnecting the notion of God's love for sinful and alienated humankind, and God's incarnational mystery to save them, Groody (2009:649) argues that migration formed Jesus' self-understanding as the Gospel of John 13:1, 3 attests:

Having loved his own who were in the world, he loved them to the end ... Jesus knew that the Father had given everything into his hands, that he had come from God, and that he was going back to God. (Jn 13:1, 3; Groody 2009:649).

From this perspective, Groody (2009:649) establishes Jesus Christ who is the Word of God (Verbum Dei) as the 'great migration of human history'. This implies that 'God's movement in love to humanity makes possible humanity's movement to God'.

Notably, the migration of the Son of God to save humankind continues during his incarnation on earth as he takes upon the human mode of existence. Groody (2009:649) alludes to this point when he argues that, as an ideal God-man being, Jesus' earthly life was characterised by many stories of migration. For example, Luke 2:1-5 portrays Jesus Christ as a migrant who is facing documentation challenges, whilst Matthew 2:13-17 presents Jesus and his family fleeing a threat that endangered their lives (Groody 2009:649). In doing so, Jesus and his family become political refugees (Groody 2009). Further, John 7:41-43, 52 reveals many people that find it difficult to have faith in Jesus because of the place from which he emigrates. In Groody's view (2009), this clearly indicates that:
In migrating to the human race God enters into a place of 'otherness', the very migration that human beings fear and find so difficult to make. This movement of divinity to humanity is predicated not on laws, institutions, or any form of human merit but, above all, on God's gratuity. In crossing borders of every kind for the good of others, the Verbum Dei reveals the mystery of God's a priori, self-giving love. (p. 650)

With the aforementioned discussion in mind, Groody (2009:650) advances that the incarnation of the Word of God (Verbum Dei) means that 'for God there are no borders that cannot be crossed, neither within himself nor in the created world'. Here, Groody (2009:650) corresponds with Barth (2004) who affirms that:

The mystery reveals to us that for God it is just as natural to be lowly as it is to be high, to be near as it is to be far, to be little as it is to be great, to be abroad as it is to be at home. (p. 192)

\section{Groody's application of the doctrine of incarnation to migration issues}

The incarnation and the Great Commission as challenging the church to embrace and integrate migrants

In Groody's view (2009), the incarnational mystery of God has many lessons that can help migrants to cope. The view also challenges the church of God to adopt a more positive response to migrants' challenges. Emerging from the previous discussion ('Groody's articulation of the doctrine of incarnation in view of sin' and 'Groody views the incarnation as central in solving the internal and external justice that was diminished by $\sin ^{\prime}$ sections), is the lesson that, although humankind can construct barriers of all kinds against each other, including migrants, the incarnation advises us that God does not exclude anyone from the divine embrace (Groody 2009:650). This amply demonstrates that Groody (2009:653) believes that, in the incarnational mystery, God identifies with all people in and through Christ. After identifying with all people, Christ suffers for their sins to the point of death at the cross (Groody 2009). Given this, Groody (2009) insists that the mission of God in the incarnational mystery is to restore the image of God to all people who have faith in the redemptive work of Jesus Christ (Groody 2009). Unfortunately, without bringing the aspects that configure his concepts of Christ as the representative of all humanity in the incarnation (so that he dies at the cross to save all humankind that believe in his saving work), Groody substantiates his notion of the incarnation as inclusive of all people by bringing the Great Commission in Matthew 28:16-20 to bear in this discussion.

Groody (2009:653) contends that, after his death and resurrection, Jesus sanctions his followers in Matthew 28:16-20 to preach the good news of salvation to people of nations. This charge encompasses the need for the disciples to fight against all the forces of sin that consistently seek to damage the image of God in humanity, which Christ comes to restore (Groody 2009). Here, Groody (2016:231) notes that, whilst globalisation has made it easier for money, goods and services to move across borders, it follows that the movement of people across the borders remains a challenge. It is further 
posited that the issue of nations constructing high walls (i.e. harsh visa requirements) makes it extremely difficult for people to migrate from one country to another (Groody 2016). These high walls result in migrants resorting to using dangerous routes, resulting in some of them failing to reach their desired destinations. However, Groody (2016:231) perceives the physical walls that are built by nations as less restrictive than those that are built by people against one another in their hearts (Groody 2016). These high walls that nations build to keep out migrants, as well as the onerous visa requirements are just a reflection of the built-in walls in people's hearts against one another (Groody 2016), which make it difficult for the natives to consider migrants' interests before their own. Generally, the failure of people to look beyond their own self-interest makes it difficult for them to respond to the collective needs of communities, nations and the world at large. Groody (2016) summarises the preceding conversation in the following manner:

Such narcissism has taken on not only an individual and personal dimension but a collective and national dimension as well. In the process we have lost a sense of our own human dignity and our interconnected nature as human beings. In addition, we have lost not only a sense of the common good for our nations but even that of our peoples. (p. 1)

In response to the unseen walls, which people build against each other in their hearts, Groody (2016:23) challenges the church to uphold its Great Commission (cf. Matthew in Mt 28:16-20) in which Jesus sanctions his followers to take the gospel to all people. The church and, consequently, Christians uphold the Great Commission by preaching the gospel of reconciliation between God and humanity, as well as human and human (Groody 2016). This is because, from a Christian perspective, 'a central dimension of theological reflection pertains to overcoming all that divides human relationship by working toward the mission of reconciliation' (Groody 2016:231). Here, Jesus's ministry of reconciliation is a paradigm of how the church should operate. Jesus' ministry of reconciliation deals largely with overcoming the human construction such as laws that discriminate the insider from the outsider. Stated differently, Jesus' mission and ministry of reconciliation challenge the inclination of people to worship nations, religion and particular philosophies that ascent to be used as a 'force that excludes and alienates, even when it does so under the guise of obedience to a greater cause' (Groody 2016:232). In Groody's view (2016), Jesus' ministry of reconciliation entails:

Jesus' openness to Gentiles, his approach to the Syrophoenician or Canaanite woman, his response to the Roman centurion, and many other encounters illustrate Jesus' willingness to go beyond borders and narrow interpretations of the Law in obedience to a greater law of love. Jesus recognized the value of the Law, but he also challenged people to see the larger picture of the Law and to understand its deeper meaning. By his words and actions, Jesus demonstrates that compassion requires a reading of the Law that gives primary consideration to meeting human needs. (p. 232)

\section{The kenosis theory of Jesus Christ as challenging the church to identify more with vulnerable migrants}

In line with Power (2005:4), Groody (2009:651) underscores that the concept of Christ's self-emptying (kenosis) is critical to challenging the church of God to identify more with the poor such as the vulnerable migrants. The kenosis of Christ compels the church and, consequently, Christians to emulate Christ by fighting for justice for the poor. The church is also called to fight against the prevailing forces that do not encourage co-existence between migrants and the native people (Groody 2009). Stated otherwise, emulating Christ entails that the church completely identifies with all vulnerable people, as well as participates in the selfsacrificial love of God by loving the poor people as God loves them in Christ. Imbedded in the aforementioned conception is that the acts of empathy, love and compassion for deprived people such as vulnerable migrants is the appropriate response of Christians to their God's gracious redemption in and through the God-man, Jesus Christ's redemptive work (Groody 2009). Groody (2009) captures the aforesaid notion of the incarnation as he argues that, although it is saving, it also:

... challenges especially those who exclude on the basis of superficial notions of private property, legal status, and personal or even national rights without any social, moral, or divine reference point, or any regard for the exigencies of distributive, contributive, and restorative justice that flow as a natural consequence from divine gratuity. The incarnation moves people beyond a narrow, self-serving identity into a greater identification with those considered 'other' in society, particularly those like migrants and refugees who are poor and regarded as insignificant. (p. 652)

\section{The incarnation as a risky movement of God that operates as a coping mechanism for migrants}

In Groody's view (2009:650), the incarnation is a risky movement of God that can operate as a coping mechanism for migrants. The movement of God in and through Christ into the strange and alienated constituency of sinful humanity was a risky movement into the broken world of humankind (Groody 2009:651). The incarnation of God can be regarded as a really risky programme only if it had not achieved its redemptive purpose for humankind (Groody 2009:651). Using the concept of the risky movement of God in the incarnation, Groody (2009) further argues that many migrants understand their migration in light of God's risky movement in the incarnation (Groody 2009). Numerous migrants reframe their narratives of migration in light of God's incarnational mystery, owing to the fact that they move from their countries of origin and undertake dangerous journeys to foreign nations where there is no certainty of regaining what they would have foregone in their home countries (Groody 2009). Stated differently: migrants are of the opinion that as God, in and through Christ who emptied himself of his divine privileges (as fully God) in the incarnational mystery, they are also emptying themselves by giving up everything they owned in their countries of origin and commencing risky journeys to faraway places without any guarantee of recovering what 
they would have left behind in their countries of origin (Groody 2009:651). In Groody's words (2009):

The kenosis of Jesus is God's radical risk of movement into the broken territory of human life, with potentially cataclysmic consequences if it fails. For many compelling reasons, numerous migrants and refugees reframe their own story in the light of Jesus' journey. Leaving their homelands, undergoing dangerous journeys, and taking up residence in a foreign land not only entails emptying themselves but radically surrendering everything they own, without any assurance that what they lose will come back to them. (p. 651)

This means that the conception of the incarnation as a risky movement by God is critical in giving hope to many migrants, as they hope that their own risky movements to new countries will change their lives for better. In other words, because the purpose of God's risky movement into the strange and alienated world of sinful humanity is successful, given that it saves humankind, it follows that migrants may identify themselves with Jesus and, consequently, hope their lives in foreign nations will change for the better. However, the conception of the incarnation as a risky movement by God is problematic, because it fails to put into perspective a thorough understanding of the doctrine of God. I do not subscribe to Groody's notion of the incarnation (2009) as a risky movement by God, because it poses challenges to my understanding of the doctrine of God who is the creator of the universe and everything within it (Col 1:16), and is omnipotent (Col 1:6), omniscient (Heb 4:12-13) and omnipresent (Col 1:17). Further, as Hebrews 1:3 notes, God is not a passive observer of creation; instead, God sustains it by the power of the Word, Jesus Christ, the very God himself (Heb 1:3). Thus, as the sovereign Creator and sustainer of the universe who is omnipotent, omniscient and omnipresent, it follows that God knows everything and there is nothing that can thwart the divine redemptive purposes and plans for humankind that Jesus comes to accomplish by taking the human form of existence in the incarnation.

Furthermore, the reframing of migrants' narratives along the incarnation is problematic, because the causes of God's and migrants' movements are different. I am cognisant that God's incarnation to save humankind comes from divine eternal love, whilst human migration is caused by natural disasters (climate change) and human-made causes, for example religious, political and economic instability, among many others. This means that, although migrants can be assisted to find hope in their new homelands, reframing their migration stories in light of the incarnational mystery of God is flawed, as it is apparent that God's migration remains distinct from human migration in the proposed manner. Indeed, this begs one to establish the dogma of the incarnation in light of the trinitarian doctrine of God.

\section{Identified weaknesses in Groody's conceptualisation of the doctrine of incarnation}

Emerging from the abovementioned discussion is that Groody (2009) applies the doctrine of incarnation to challenge the church of God and the native people to co-exist with foreigners and embrace them, as this helps the migrants to cope in their new homelands. Nonetheless, Groody's doctrine of incarnation (2009) is not well-articulated, probably because he assumes that his readers are aware of the concept. Instead, he focuses more on bringing his sketched doctrine of the incarnation (in the previous sections) to respond to the contemporary challenges of migration and, consequently, migrants. It can, thus, be argued that there are a few aspects that lack thorough theological articulation in Groody's theology of incarnation (2009). Firstly, Groody (2009) does not establish the trinitarian doctrine of God that establishes Christ as fully God. Instead, the deity of Christ is stated in his wider discussion, but without being explained. However, this does not mean that Groody (2009) does not view Christ as fully God.

Secondly, Groody (2009) does not identify or discuss the various theological aspects that he brings together to configure his doctrine of Christ as the representative of all humanity in the incarnational mystery and, consequently, saves those that believe in his (Jesus Christ's) redemptive acts from sin and all its consequences. Thirdly, Groody (2009) seems to view the incarnation as a risky movement. As argued before, the conceptualization of the incarnation as a risky movement of God that operates as a coping mechanism for migrants portrays God as oblivious of exactly how the redemption of humankind would be accomplished when, in the incarnational mystery, the divine takes upon the human nature. Consequently, this poses a challenge to our understanding of God, who is sovereign, omnipresent, omnipotent and omniscient. Having identified the weaknesses in Groody's (2009) understanding of the incarnation, in the ensuing subsections, this article will now delineate the doctrine of the incarnation in view of the Trinitarian doctrine of God so as to countermand the identified weaknesses in Groody's (2009) proposed doctrine of incarnation.

\section{Articulation of the doctrine of incarnation in view of the doctrine of God: Towards countermanding weaknesses in Groody's doctrine of incarnation}

\section{God's incarnation and its purpose to save humankind: The God-man, Jesus Christ, fulfils Israel's redemptive role}

Nkansah-Obrempong (2010:294; cf. Torrance 1981:xviii) rightly observes that the 'Evangelical theology is simply Trinitarian Theology in nature'. However, I am conscious that Nkansah-Obrempong's definition (2010) can be challenged, because it can be perceived as limiting evangelical theology to the doctrine of the Trinity. Yet, the former entails many theological aspects, that is, Scripture as the Word of God, and Jesus Christ and his saving work (Runia n.d.:293-304). In response to this, I argue that NkansahObrempong (2010) is not limiting evangelical theology to the 
doctrine of the Trinity. Instead, the doctrine of the Trinity is fundamental to evangelical theology. By avowing that the evangelical theology is trinitarian in nature, this article asserts that God exists as three persons, namely Father, Son and Holy Spirit, but one being (Torrance 1995:131; 1996:15). The trinitarian doctrine views God as one existence, but three distinguishable persons (Torrance 1995; 1996). Clark (2006:91-102), who analyses Augustine's doctrine of the Trinity, agrees that Scripture represents the Trinity as coequal, co-eternal, one in essence, power, will and action. This means that every Person of the Trinity should be comprehended as having the same nature as the other Persons, although they have different functions to play in the economy of salvation (Clark 2006).

In linking the abovementioned understanding of the trinitarian doctrine of God with the incarnation, this article argues that the incarnational mystery of God entails that, in and through Christ, the omniscient, omnipotent and omnipresent God moved into the bounds of space and time in order to have complete solidarity with all humankind for the sake of their salvation. This understanding views all humankind as being in the pandemic of sin that alienates them from God (cf. Rm 3:23; 5:12-21; 1 Cor 15:21-22). In examining Romans 5:12-21, which is a critical New Testament text in understanding the doctrine of original sin, a considerable number of commentators such as Fitzmyer (1993:135-136), Schreiner (1998:274-277), Jewett (2007:281) and Moo (1996:326-328) argue that this is a text that defines human identity as either found in Adam or in Christ. Although there are some theologians who do not uphold the doctrine of original sin, Berkouwer (1971:425-451) notes that most theologians and commentators subscribe to it. However, they differ when it comes to the way sin was inherited by all humankind. Here, many scholars subscribe to two dominant positions, namely realism and federal (Berkouwer 1971:439). The realism position views all humankind as having co-sinned with Adam in the Garden of Eden, whilst the federal position refers to the sin of Adam as having been imputed to all people and therefore subjecting Adam to being a mere representation of humankind as a covenantal head (Berkouwer 1971:439). However, although these aforesaid stances have their own strengths and weaknesses, I argue with Moo (1996:329) that, derived from Romans 5:12-21, all people are sinners because of Adam's sin. Moo (1996:392) describes sin in the following manner: 'Whether we explain this solidarity in terms of sinning in and with Adam or because of a corrupt nature inherited from him (Adam) does not matter at this point.'

However, from the Old Testament, one perceives God's grace to save people from sin, as God calls and enters into a covenantal relationship with Abraham and his descendants (i.e. the nation of Israel) to be priestly people that will be the vehicles of God's great redemption to all people of the earth (Magezi 2016:155). That is to say, this article takes cognisance of the fact that the universal salvific promises of God, which are introduced to Abraham in Genesis 12:3, are renewed with his (Abraham's) descendants (Magezi 2018:34). For example, God's liberating promise to Abraham's descendants as vehicles of that salvation is reinstated to Isaac (Gn 26:3-5) and Jacob (Gn 32:9-12; 35:12). This covenant and its promises are later on cited in Exodus 2:24 and 6:4-5 as the basis for God's deliverance of the Israelites from Egyptian bondage (Magezi 2018). This means that 'God's redemptive narrative, particularised in Israel' is designed by God to save people of all nations (Magezi 2016:155). However, Israel cannot accomplish her redemptive role, as she is also under the pandemic of sin; thus, in the incarnation, the fully God-man, Jesus Christ, stands in the place of Israel to fulfil God's redemption for humankind (Torrance 2009:9).

\section{Possible challenges posed to the doctrine of God by the incarnation}

I am conscious of the Greek philosophical thinking that attempts to understand God in a way that drives a wedge between Jesus Christ and God. Torrance (1992:63) and Mascall (1946:14) argue that the Greek cosmological thinking projects the existence of two different worlds, namely the real and unreal that do not interact with each other. God belongs to the real world of eternal existence that does not change (immutable) or constitute any form of suffering (impassible), whilst human beings belong to the unreal world that does not have eternal existence, that is, an evil realm of suffering, decay and change (Torrance 1981:5; 1996:34-35). In doing this, the Greek cosmological thinking reduces Jesus to a mere human who was adopted at a certain point in time to be in a special relationship with God in order to accomplish God's redemptive purpose of saving humankind from sin and all its consequences. The aforementioned understanding is a challenge to the doctrine of salvation that perceives Jesus Christ as the very God who offers vast and comprehensive salvation to the entire world (Torrance 2009:196).

Nevertheless, from a close look at the Christian doctrine of God, Barth (1957:269), Mascall (1946:14) and Torrance (1981:6-7; 1996:237) observe that the dogma of immutability denotes God as an 'intrinsically and eternally dynamic being', who cannot be caused to move by anything external. Therefore, because of everlasting love (1 Jn 4:8-16), God, in the incarnation, moved to assume creaturely existence for the sake of humanity's redemption (Torrance 1996:244-246). This means that, whilst the factors of human migration are natural disasters (i.e. climate change) and human-made causes (i.e. political instability, economic instability, wars, religious persecution, pursuit of education, tourism, etc.), God is not moved by something external, but by eternal love for people. Likewise, Barth (1957:269) notes that the doctrine of God's immutability speaks about God as someone who is not moved by anything external. In Barth's words (1957) God is not the being moved in and by us which we think we know or think we know as our movement of nature and spirit. Instead, God's migration to assume our human mode of existence in order to save humankind is self-motivated, because divine decisions are 'independent of the decisions by 
which we validate our existence ...' (Barth 1957:269, 271). Stated otherwise, God's movement is:

[God's] executed decision - executed once for all in eternity, and anew in every second of our time, and therefore in such a way that it confronts what is not being, not as mere possibility, but always as a self-containing reality. (Barth 1957:271)

The doctrine of impassibility suggests that God cannot feel compassion for something that is outside of himself (Torrance 1981:6). This means that when it comes to God, one should '... think of all the changes in God's mighty acts of creation and redemption which constantly surprise us as flowing from and reposing upon his eternally unchanging life' (Torrance 1996:236).

Having established the abovementioned understanding of the dogmas of impassibility and immutability in relation to God, this article contends that the incarnation of God in and through Christ is not a risk of movement as Groody (2009:651) seems to indicate in his attempt to draw parallels between God and the contemporary migration of human beings. This article further argues that, out of eternal love, the all-knowing (omniscient) God moves into the world of estranged humankind to accomplish a specific purpose, namely to assume the human mode of existence and save humankind from sin and all its consequences. Thus, as argued before, the incarnation is not God's risk of movement in such a way that God might think that the incarnational salvific purpose for humanity could not have worked. Instead, as a being who knows everything, God abdicates divine privileges and migrates from heaven to earth to completely identify with all humankind and save them from sin and its consequences. If one conceives the incarnation as a risky movement for God, he or she may be thinking that God lacks knowledge to distinguish what is going to happen in the world of eternal existence and within the world of creature existence that God created. This conception is incompatible with the Bible that denotes God as someone who is not surprised by what takes place in both the world of eternal existence or the world of creaturely existence that the all-knowing God created (cf. Ps 147:5; 1 Jn 3:20; Ps 139:4; Heb 4:13; Is 46:9-10, etc.).

\section{The inclusion of all humanity in the vicarious humanity of Christ: Anhypostatic and enhypostatic concepts}

Notably, Groody (2009) speaks about Christ's identification with all humanity in the incarnation without delineating the concepts that he brings together to configure the aspect of Christ as truly identifying with all humanity in the incarnation. Thus, in making up for this weakness in Groody's doctrine of incarnation (2009), I first agree with the doctrine's assertion that Christ identifies with all people in the incarnation. However, I move beyond that assertion by bringing forth the couplet Greek theological concepts, namely anhypostasis and enhypostasis as two important thoughts that describe Jesus' relationship to human nature (Barth 1958:49; Moltmann 1974:231; Torrance 2008:84, 230-232; 2009:1xxii). However, I am conscious of critics such as Gockel (2000:515-532) who consider the anhypostasisenhypostasis theory as a dubious Christological formula, as it is an inappropriate way of expressing the relationship between the divine and human natures in the person of Christ. However, regardless of this critique, I argue that, if understood properly, the anhypostasis and enhypostasis concepts underscore the once and for all solidarity between 'Christ and all mankind' that takes place in the incarnational mystery (Gockel 2000).

Torrance (2008:84, 229; 2009:1xxiii), Barth (1958:49) and Moltmann (1974:231) state that the anhypostatic union affirms the negative that the general or common human nature of Jesus Christ has no independent grounding. The enhypostatic union upholds the positive that, in the incarnation, the human nature of Christ is grounded in the eternal person of the divine Logos (Moltmann 1974). This means that the human nature of Christ acquires real existence and stability in the existence of God (Moltmann 1974). At this juncture, together with Barth (1958:49) and Torrance (2008:230), I am conscious of the possible objection that arises in affirming the human nature of Jesus Christ as not having an independent person of its own. Stated otherwise, the notion that the human nature that is assumed by Jesus Christ in the incarnation does not have a person of its own, results in one denying the real humanity of Jesus Christ, which is termed as docetic thinking (Torrance 2008). Docetic thinking about the humanity of Christ has negative consequences for the soteriology, because Jesus Christ has to be truly human and God, so that he can save mankind from the ontological depths of their existence from the sides of both God and humankind (Torrance 2008). However, in response to this possible objection, I argue, together with Torrance (2008:230), that using the concept of enhypostatic union to the vicarious humanity of Christ, does not mean that '... in the incarnation there was no particular individual called Jesus existing as a particular human being, with a rational human mind and will and soul'. Instead, I opine that, in his earthly days, Jesus was a true human being who possessed a full 'human mind and human soul and human will' in his 'hypostatic union with divine life' (Torrance 2008:230).

However, the true identification of God with humanity in the incarnation means that God becomes sinful like humankind. Here, although Jesus assumes a general human nature in the incarnation that represents all humanity, it follows that his nature is like that of mankind in some respects, but also unlike humanity in other respects (Sumner 2014:192). A considerable number of scholars (i.e. Athanasius 1953:34; Barth 1956:190-196; Macleod 1998:225; O'Collins 1995:273-278; Torrance 2008:88, 101, 102-104) view the supernatural sign of the virgin birth as revealing that, in the incarnation, the Son of God is not sinful; instead, he is a perfect, holy and righteous God who assumes sinful human nature and sanctifies it for the sake of our redemption. Athanasius (1953:34) indicates that the absence of the 'agency' of a 'human father' is vital in pointing out that Christ takes upon 'spotless' or 'a pure' human flesh in the incarnation. Similarly, Barth $(1956: 191,192)$ explains that in the miraculous 
sign of Jesus' conception, 'sin is excluded and nullified'. However, the exclusion of a male in Mary's conception of Jesus does not designate the Virgin Mary as sinless. Here, one does well to concur with Barth's explanation (1956) that:

It is not as if virginity, as a human possibility, constitutes the point of connection for divine grace ... The sinful life of sex is excluded as the source of human existence of Jesus Christ, not because of the nature of sexual life, nor because of its sinfulness, but because every natural generation is the work of willing, achieving, creating, sovereign man. (p. 192)

Nonetheless, in conceding to the previous understanding, I am not leaning towards Macleod's understanding (1998:229) that the human nature, which Christ assumes at the incarnation, is Adam's pre-fallen human nature. Although the divine sign of Mary's conception nullifies the Adamic sin in Jesus Christ, it can be contended that Jesus Christ assumes Adam's human nature after the fall, which is both unique and similar to contemporary human nature. In other words, the virgin birth points us to the sinlessness of the human nature of Christ in relation to the Adamic or original sin as presented in Genesis 3 (Macleod 1998:221-222). Stated otherwise: although the human nature of Christ is Adam's human nature after the fall, the divine sign of the virgin birth points us to the actuality that:

... when the holy Son of God took our sinful humanity upon himself, he did it in such a way that instead of sinning himself, he brought his holiness to bear upon it so that it might be sanctified in him. (Torrance 1995:184)

In using the anhypostatic and enhypostatic concepts, Sumner (2014:211-212) helpfully observes that the immaculate sign of the virgin birth affirms that the human nature of Christ 'is anhypostatically fallen and enhypostatically sanctified' in the person of the divine Logos. However, by arguing that God in Christ identifies with all people in the incarnation, I am not pointing to universalism, which I understand is a heresy for faith and a threat to the gospel, and thus making the predominant phrase 'faith in Christ' meaningless (cf. Torrance 2009:181-189).

\section{Reinforcement of Groody's key applications of the doctrine of incarnation in challenging the church to embrace migrants and address their challenges}

Having established the notion of God's true identification with all humanity in the incarnational mystery, and paid attention to the various issues clarified in the above sections, I agree with Groody (2009:650) in advancing the incarnation as advising humankind that God does not exclude anyone from his divine embrace. This is because, in the incarnational mystery, out of divine love, God identifies with all people in and through Christ. Subsequently, after identifying with all people in and through Christ's incarnation, the God-man, Jesus Christ, suffers at the cross for the sins of humankind to the point of death. In following this Christological paradigm of the incarnation, the church of God is challenged to emulate God's love in the incarnation by embracing and co-existing with all people, including migrants. The church of God and, consequently, Christians should not exclude people on the basis that they are foreigners or come from cultural, ethnic, national or religious backgrounds that are different from theirs. In view of the migration crisis, the church should embrace all migrants and address their needs regardless of their backgrounds and status, as Christ embraces all humankind in the incarnation.

In substantiation of the aforementioned, it can be opined that the kenosis concept of Christ, which Groody (2009) also highlights in his discussion of the incarnation, can now be used to reinforce the challenge for the church to identify more with migrants and assist them to cope with various challenges. Therefore, as Christ devoid himself of his divine privileges as God, so as to identify with mankind for the sake of their redemption, it follows that his followers (Christians) should emulate this Christological model by meeting the needs of migrants despite the cost that is incurred. This means that, just like Christ, the church is challenged to leave its comfort zone and meet the needs of vulnerable people such as migrants.

\section{Conclusion}

In conclusion, this article has argued that the church is obligated by God to respond to migrants' challenges. As the Church responds to migrants' challenges, the theological foundational status of migration theology that challenges the body of Christ to embrace and integrate migrants are at stake. With this in mind, this article considered Groody, who has offered a theological foundational status of migration theology that challenge the church to be practically responsive to the plight of migrants, as the leading theologian in migration discourse. The article established that Groody advances the theology of the incarnation as the major theology of migration, with far-reaching implications on this subject. Unfortunately, Groody's theology of the incarnation has weaknesses in both conceptualisation and application. In addressing the weaknesses in Groody's conceptualisation and application of the incarnation doctrine in urging the church to be proactively involved in migration issues, this article went beyond Groody by articulating the doctrine of the incarnation so as to counteract the weaknesses arising from his conceptualisation and the application of this doctrine. For instance, Groody's conception that Christ identifies with all humankind in the incarnation is reinforced by the couplet Greek theological concepts, namely anhypostasis and enhypostasis. In using the aforesaid concepts, this article argued that, in the incarnation, God in and through Christ assumes a general human nature that represents all humankind. After clarifying the notion of Christ's identification with all humanity in the incarnation, using the anhypostasis and enhypostasis concepts, the article sustained Groody's notion (2009) that Christ truly identifies with all humanity in the incarnation and dies for them at the cross. As a result, the church and, consequently, Christians should 
emulate the incarnational mystery of God by embracing and co-existing with all migrants, as God, in Christ's incarnation, embraces all people. This challenges the church to be the model of the sacrificial love of God. The church can demonstrate this by leaving its comfort zone and incurring the costs (i.e. money and time) of addressing the migrants' material, spiritual and other associated needs.

\section{Acknowledgements Competing interests}

The author declares that no competing interest exist.

\section{Author's contributions}

I declare that I am the sole author of this research article.

\section{Ethical consideration}

This article followed all ethical standards for carrying out research.

\section{Funding information}

This research received no specific grant from any funding agency in the public, commercial, or not-for-profit sectors.

\section{Data availability statement}

The author confirms that the data supporting the findings of this study are available within the article.

\section{Disclaimer}

The views and opinions expressed in this article are those of the author and do not necessarily reflect the official policy or position of any affiliated agency of the author.

\section{References}

Arnold, T.P., 2008, Two stage biblical creation: Uniting biblical insights uncovered by ten notable creation theories, Thomas Arnold Publishing, Arlington Heights, IL. Athanasius, 1953, St Athanasius on the incarnation, 2nd edn., Mowbray, London.

Averbeck, R.E., 2013, 'A literary, inter-textual, and contextual reading of Genesis 1-2', in J.D. Charles (ed.), Reading Genesis 1-2: An evangelical conversation, p. 30, Hendrickson Publishers, Peabody, MA.

Barrick, W.D., 2013, 'A historical Adam: Young-earth creation view', in A.B. Caneday, S.N. Gundry \& M. Barret (eds.), Four views on historical Adam, pp. 228-252, Zondervan, Grand Rapids, MI.

Barth, K., 1956, Church dogmatics: The doctrine of the Word of God, vol. 1, part 2, transl. G.T. Thomson \& H. Knight, T\&T Clark, Edinburgh.

Barth, K., 1957, Church dogmatics. The doctrine of God, vol. 2, part 1, transl. G.W. Bromiley \& T.F. Torrance, T\&T Clark, Edinburgh.

Barth, K., 1958, Church dogmatics. The doctrine of reconciliation, vol. 4, part 1, transl. G.W. Bromiley \& T.F. Torrance, T\&T Clark, Edinburgh.

Barth, K., 2004, The doctrine of reconciliation: Church dogmatics, transl. G.W. Bromiley \& T.F. Torrance, Continuum, New York, NY.

Beidler, M., 2011, 'A response to Tim Keller's "killer argument" against a mythological Adam', from his blog "Rethinking the alpha and omega"', viewed 03 August 2020, from unsettledchristianity.com ' another-response-to-tim-kell ....

Berkouwer, G.C., 1971, Studies in dogmatics sin, William B. Eerdmans, Grand Rapids, MI.

Botha, N.A., 2013, 'A theological perspective on migrants and migration focussing on the Southern African Development Community (SADC)', Missionalia 41(2), 104-119. https://doi.org/10.7832/41-2-8

Clark, M.T., 2006, De Trinitate, Cambridge Companions Online, Cambridge University Press, viewed 18 February 2020, from www2.bc.edu , taylor-black , DeTrinitateSummary.
Cruz, G.T., 2010, An intercultural theology of migration: Pilgrims in the wilderness, Brill, Leiden.

Fitzmyer, J.A., 1993, Romans: A new translation with introduction and commentary, Geoffrey, London.

Gockel, M., 2000, 'A dubious Christological Formula? Leontius of Byzantium and the anhypostasis-enhypostasis theory', The Journal of Theological Studies 51(2), 515-532. https://doi.org/10.1093/jts/51.2.515

Groody, D.G., 2009, 'Crossing the divide: Foundations of a theology of migration and refugees', Theological Studies 70(3), 638-667. https://doi.org/10.1177/ 004056390907000306

Groody, D.G., 2016, 'Migration: A theological vision', in J.B. Saunders, E. FiddianQasmiyeh \& S. Snyder (eds.), Intersections of religion and migration: Issues at the global crossroads, pp. 225-239, Palgrave Macmillan, New York, NY.

Jackson, D. \& Passarelli, A., 2016, 'Mapping migration, mapping churches' responses in Europe: Belonging, community and integration: The witness and service of churches in Europe', viewed 26 August 2017, from www.ccme.be/.../2016-0108Mapping_Migration_2015_Online_lo-res_2_.pdf.

Jewett, R., 2007, Romans: Hermeneia - A critical and historical commentary on the Bible, Fortress Press. Minneapolis, MN.

Macleod, D., 1998, The person of Christ: Contours of Christian theology, InterVarsity Press, Leicester.

Magezi, C., 2016, 'The conceptualisation of Christ's salvation in Kwame Bediako and Thomas F. Torrance and its implications for spiritual security in African Christianity', MA thesis, North-West University (Potchefstroom Campus), Potchefstroom.

Magezi, C., 2017, 'Migration crisis and the church: A response to lacunae and considerations for Christian ministry engagement', Verbum et Ecclesia 38(1), a1671. https://doi.org/10.4102/ve.v38i1.1671

Magezi, C., 2018, Theological understandings of migration and church ministry model: A quest for holistic ministry to migrants in South Africa', MA thesis, NorthWest University, Potchefstroom.

Magezi, V. \& Magezi, C., 2018, 'Migration crisis and Christian response: From Daniel De Groody's image of God theological prism in migration theology to a migration practical theology ministerial approach and operative ecclesiology', HTS Teologiese practical theology ministerial approach and operative ecclesiology', HTS Teologiese
Studies/Theological Studies 74(1), 4876. https://doi.org/10.4102/hts.v74i1.4876

Mascall, E.L., 1946, Christ the Christian and the church: A study of the incarnation and its consequences, Longmans, London.

Mitch, C. \& Sri, E., 2010, The gospel of Matthew: Catholic commentary on sacred Scripture, Baker Academic, Grand Rapids, MI.

Moltmann, J., 1974, The crucified God, SCM Press Ltd, London.

Moo, D., 1996, The epistle to the Romans: The new international commentary in the New, William B. Eerdmans Publishing, Grand Rapids, MI.

Morris, L., 1992, The gospel according to Matthew, William B. Eerdmans Pub. Co, Grand Rapids, MI.

Mounce, R.H., 1985, Matthew: New international commentary, Hendrickson Pub, Peaboy, MA.

Nkansah-Obrempong, J., 2010, 'Evangelical theology in Africa: Ways, perspectives, and dilemmas', Evangelical Review of Theology 34(4), 293-299.

O'Collins, G.J., 1995, Christology: A biblical, historical and systematic study of Jesus, Oxford Press, Oxford

Power, D.N., 2005, Love without calculation: A reflection on Divine Kenosis: He emptied himself, taking the form of a slave, Philippians 2:7, Crossroad Publication Company, New York, NY.

Runia, K., n.d., 'What is evangelical theology', viewed 03 August 2020, from biblicalstudies.org.uk> pdf > ert > evangelical_runiaPDF.

Saunders, J.B., Snyder, S. \& Fiddian-Qasmiyeh, E., 2016, 'Introduction: Articulating intersections at the global crossroads of religion and migration', in J.B. Saunders, E. Fiddian-Qasmiyeh \& S. Snyder (eds.), Intersections of religion and migration: Issues at the global crossroads, pp. 1-45, Palgrave Macmillan, New York, NY

Schreiner, T., 1998, Romans: Baker exegetical commentary on the New Testament, William B. Eerdmans Publications, Grand Rapids, MI.

Sumner, D.O., 2014, 'Fallenness and anhypostasis: A way forward in the debate over Christ's humanity', Scottish Journal of Theology 62(2), 195-212. https://doi. org/10.1017/S0036930614000064

Torrance, T.F., 1981, Divine and contingent order, Oxford University Press, Oxford.

Torrance, T.F., 1992, The mediation of Christ, W.B. Eerdmans Publishing Company, Grand Rapids, MI.

Torrance, T.F., 1995, The Trinitarian faith, T\&T Clark, Edinburgh, NY.

Torrance, T.F., 1996, The Christian doctrine of God: One being three persons, T\&T Clark, Edinburgh, NY.

Torrance, T.F., 2008, Incarnation: The person and life of Christ, IVP Academic, Downers Grove, IL.

Torrance, T.F., 2009, Atonement: The person and work of Christ, IVP Academic, Downers Grove, IL.

Turner, D.L., 2008, Matthew: Baker exegetical commentary on the New Testament, Baker Academic, Grand Rapids, MI.

World Council of Churches (WCC), 2015, 'A worldwide fellowship of churches seeking unity, a common witness and Christian service', viewed 03 March 2020, from www.oikoumene.org > self-understanding-vision > cuv 